\title{
Prevalence of Prehypertension in Nigeria: a Systematic Review and Meta-analysis
}

\author{
Bashir, M.A. *, Yahaya, A. I., Muhammad, M., Yusuf, A.H. \\ Department of Anatomy, Bayero University, Kano, Nigeria
}

*. Corresponding author: M.A. Bashir, Department of Anatomy, Bayero University, Kano, Nigeria. Tel: +2347036878467, E-mail: musabashir34@gmail.com.

Cite this article: Bashir, M.A.; Yahaya, A.I.; Muhammad, M.; Yusuf, A.H. Prevalence prehypertension in Nigeria: A systematic review and meta-analysis. Int $\mathbf{J}$ Epidemiol Health Sci 2021;2(9): e20. Doi: 10.51757/IJEHS.2.9.2021.245213.

\begin{abstract}
Background: Prehypertension is a low blood pressure state associated with an elevated risk of cardiovascular disease and the development of hypertension. Everyone is concerned about the rising global burden of hypertension and prehypertension. The goal of this study was to determine the prevalence of prehypertension in Nigeria.

Methods: Studies were chosen based on predefined criteria after doing online searches of Google Scholar, PubMed, and the African Index Medicus. The meta-analysis comprised 21 studies with a total of 25839 participants that were completed between 2011 and 2021.

Results: The pooled prevalence of prehypertension in Nigeria was found to be $34 \%$ (95\% CI: 30\%-40\%), corresponding to 41.4 million adults. Males have a higher prehypertension prevalence of $39.1 \%$ (95\% CI: 30.9\%-47.6\%) than females, with a prevalence of $28.5 \%$ (95\% CI: $21.2 \%-36.4 \%$ ). Between the sexes, there were no statistically significant differences. While the North-East had the lowest rate of prehypertension (18\%), the North-West had the greatest rate of prehypertension (43\%), indicating a statistically significant differential between the regions. However, when compared to metropolitan settlements (37\%), rural areas have a pooled frequency of 32 percent.

Conclusion: There were no statistically significant differences in gender or between rural and urban communities. There was, nevertheless, a statistically significant difference across the regions. Prehypertension is common in Nigeria, and it indicates a future risk of hypertension and other cardiovascular disorders.
\end{abstract}

Keywords: Prehypertension, Prevalence, Systematic review, Meta-analysis, Nigeria

\section{Introduction}

Blood pressure that is abnormally high is known as hypertension. From a systolic blood pressure (SBP) of $115 \mathrm{mmHg}$ and a diastolic blood pressure (DBP) of 75 $\mathrm{mmHg}$, the risk of cardiovascular disease grows in a log-linear pattern, with the risk of cardiovascularrelated death doubling every $20 \mathrm{mmHg}$ and $10 \mathrm{mmHg}$ increase in SBP and DBP, respectively (1). Despite the constant risk of rising blood pressure, identifying a cut-off number is critical for clinical and public health interventions to establish a threshold of action (2). This was described as an SBP of $140 \mathrm{mmHg}$ and/or a DBP of $90 \mathrm{mmHg}$.

Given the long-term relationship between blood pressure and cardiovascular risk, it's only natural to establish additional low-blood pressure thresholds to warn doctors and public health officials to implement low-level measures to reduce cardiovascular risk. Prehypertension (PHTN) is such a category. It is a 
borderline high-risk blood pressure status defined as SBP of 120-139 mmHg and/or DBP of $80-89 \mathrm{mmHg}$ (2). When compared to normotensive patients with a $10 \%$ yearly progression rate to hypertension, prehypertension is associated with a fourfold greater chance of developing hypertension (3). Prehypertension is related with a 200 percent increase in cardiovascular disease incidence compared to blood pressure less than $120 / 80 \mathrm{mmHg}$, in addition to the high chance of conversion to hypertension (2).

High blood pressure has becoming more prevalent over the world. In 1975, there were 594 million persons with high blood pressure, according to a pooled study of 1479 research from 174 countries with 19.1 million participants. In 2015, this number grew to 1.13 billion individuals, with the majority of the rise occurring in developing countries. Eighty-eight percent $(88 \%)$ of deaths caused by high blood pressure now occur in underdeveloped countries (4). Prehypertension was shown to be 38 percent common in a meta-analysis of 242322 people from 11 countries, including Nigeria (5).

The prevalence of prehypertension was determined to be 30.9 percent in a recent meta-analysis of 9 studies completed in Nigeria between 1995 and 2020, involving 16, 241 people (95 percent CI: 22.0-39.7). However, the analysis only included studies from four of the country's six geopolitical zones. In addition, no sex-specific prevalence of prehypertension was reported (6). This study aimed to determine the sexspecific prevalence of prehypertension across the 6 geo-political zones as well as in urban and rural settlements of Nigeria.

\section{Materials and methods}

\section{Study Area}

Nigeria is a western African country with a population of over 250 ethnic groups and a land area of 923,769 square kilometers (7). It is organized into six geopolitical zones or regions, with 36 states and a capital. In 2021, the population is expected to be 211.4 million. About $43.4 \%$ of the population was under the age of 14. In addition, 53.9 percent of the population was aged 15 to 64 years old. Only 2.8 percent of the population was above 65 years old (8). Figure 1 shows the map of the country's geopolitical zones.

\section{Inclusion and exclusion criteria}

We considered community-based studies conducted on Nigeria's adult population (over the age of 18). SBP of $120-139 \mathrm{mmHg}$ and/or DBP of $80-89 \mathrm{mmHg}$ were used to characterize prehypertension in the studies. We omitted studies involving people under the age of
18 , studies involving pregnant women, and all trials conducted in hospitals.

\section{Study search strategy}

Google Scholar, PubMed, Global, and African Index Medicus were the online databases used. The terms 'prehypertension,' 'pre-hypertension,' and 'hypertension' were used in the search. For each word containing the word "Nigeria," the search was repeated. The searches took place between March $4^{\text {th }}$ and March $15^{\text {th }}, 2021$. Two reviewers (MAB and MM) independently screened the abstracts and titles of the papers, and studies were selected and excluded based on predetermined criteria. The full-text papers were then screened independently by the same academics in order to choose studies for qualitative and quantitative analyses.

\section{Qualitative Analysis of the Included Studies}

A modified version of the Joanna Briggs Institute (JBI) Critical Appraisal Checklist for Research Reporting Prevalence Data was used to assess the methodological quality of the included studies (9). The item was decreased from nine to six questions, with each question receiving a score of one for a yes and zero for a no. The maximum possible score is six. If a study received a minimum of five points, it was considered good quality, and if it received less than five points, it was considered poor quality. Two reviewers (AIH and MM) worked independently on the assessment, with AHY resolving any differences. The modified tool used in critical assessment of the included studies is shown in Table 1. According to a recent meta-analysis of studies completed in Nigeria, the minimal sample size for ranking a study as a 'yes' was 323, calculated using the Epitools online calculator (10) and assuming a 30-percent estimated prevalence (6). The quantitative analysis includes only studies that were assessed to have good methodological quality.

\section{Data Extraction and Quantitative Analysis}

Two reviewers worked independently to obtain data (MAB and AHY). Prevalence of prehypertension, sample size, settlement (urban/rural), state and location of study, study year, mean age, and sex composition of study participants were all extracted from the studies. For statistical computing, data was loaded into Excel and then imported into the $\mathrm{R}$ statistical environment, version 4.1.0 (11).

The Metafor Package (12) was used to fit the Random Effects Model for pooling prevalence and the Mixed Effects Model for meta-regression using the inverse 
variance method with correction of pooled estimate and its variance using Sidik-Jonkman's estimator for between study heterogeneity (13).

\section{- Influence and Heterogeneity Analyses}

There were three degrees of inquiry into heterogeneity. Individual studies were initially looked into for influences, which were defined as follows:

1. The hat value, which is the standardized difference between each study's reported prevalence and the pooled prevalence, was calculated.

2. Based on rstudent, a normalized distance between each study's projected prevalence and the pooled prevalence.

3. Cook's distance is the distance between the aggregated prevalence when each study is included and when it is excluded.

4. Based on difference in fits (diffits), which is a distance in standard deviation units between pooled prevalence with the study included and when the research is omitted. The cutoff values were chosen using the $\mathrm{R}$ metafor package. In the generated influence graphs, studies that met these cut-off values were highlighted in red (14).

On a second level, gosh analysis, which is also part of the metafor package, was used to look for probable clusters in the studies that were included.

On a third level, a metaregression model was fitted using characteristics of the included studies as predictors to see how much of the computed variability can be attributable to study-level factors including sex composition, geopolitical region, settlement, mean age of the subjects, and sample size.

Prediction Intervals built in the meta R package (15) have been reported to help interpret tau 2 and $\mathrm{I} 2$ as indicators of between-study heterogeneity (16).

\section{- Publication Bias Assessment}

The Funnel plot was used to visually evaluate for probable publication bias, which occurred when papers indicating low prevalence were not published and hence were not included in the meta-analysis. Eggar and colleagues (17) used a formal regression technique to test funnel plot asymmetry.

\section{Search Results}

The results of the search strategy can be seen in Figure 2.

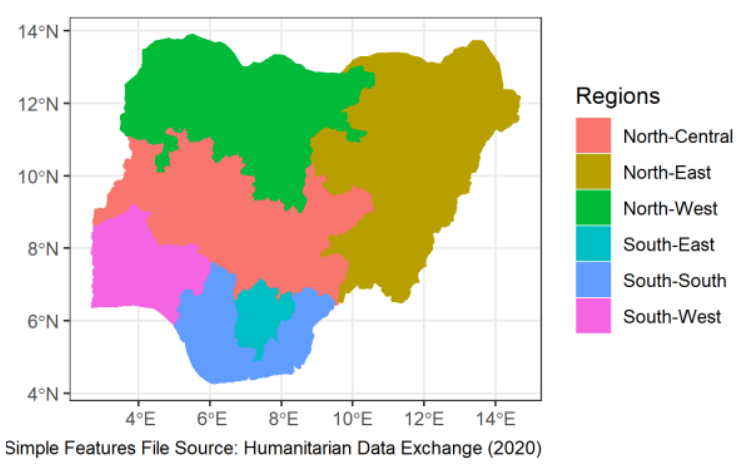

Figure 1. Geo-Political Zones in Niger

Table 1. Modified JBI Critical Appraisal Checklist for Studies Reporting Prevalence Data

\begin{tabular}{|cl|l|}
\hline \multicolumn{1}{|c|}{ Question } & $\begin{array}{c}\text { Yes }=1 \\
\text { No }=0\end{array}$ \\
\hline $1 . \quad \begin{array}{l}\text { Was the sample frame appropriate to } \\
\text { address the target population? }\end{array}$ & \\
\hline $2 . \quad \begin{array}{l}\text { Were study participants sampled in an } \\
\text { appropriate way? }\end{array}$ & \\
\hline $3 . \quad$ Was the sample size adequate? & \\
\hline $4 . \quad \begin{array}{l}\text { Were the study subjects and the setting } \\
\text { described in detail? }\end{array}$ & $\begin{array}{l}\text { Were valid methods used for the } \\
\text { identification of the condition? }\end{array}$ \\
\hline 6. $\quad \begin{array}{l}\text { Was the condition measured in a standard, } \\
\text { reliable way for all participants? }\end{array}$ & \\
\hline Total score $\quad$ & \\
\hline
\end{tabular}

\section{Results}

\section{Methodological features and the Critical Appraisal of the Included Studies}

Out of the 63 studies included in the qualitative analysis, only 21 studies were judged to be of good quality and included in the quantitative analysis. Table 2 shows the result of the qualitative analysis.

\section{Characteristics of the Studies Included in the Quantitative Analysis}

Twenty-one studies with a total of 25839 participants met the criteria for inclusion and had sufficient methodological quality to be included in the metaanalysis. The research was carried out between 2011 and 2021. There were 7 studies from the South-West region, 6 studies from the South-South, 3 studies from the South-East, 3 studies from the North-Central, one study from the North-West region and one study was conducted in all the six geopolitical regions. There 
were seven studies in rural areas, thirteen studies in urban areas, and one research that included both rural and urban areas. The average age of the study participants was 40 years in the South-South studies and 47 years in the South-East investigations. The South-West had the most participants in the study (9907), while the North-East had the fewest (1070). Studies from the country's southern areas are often larger in size and contain older individuals (Figures 3 and 4).

\section{Fitting the Meta-analytic Model}

Random Effects Model was fitted using the inverse variance method with correction of pooled estimate and its variance using Sidik-Jonkman's estimator for between study heterogeneity. Prevalence was transformed using an arcsine transformation. Figure 5 shows the forest plot of the model.

In Nigeria, the overall prevalence of prehypertension was 34 percent (95\% CI: $30-40 \%)$. According to the United Nations' most recent statistics (8), Nigeria had an estimated 41.4 million adult prehypertensive persons. The random meta analytic model had a Pvalue of 0.001 . The total between-study heterogeneity (tau2) was estimated to be 0.02 (S.E. $=0.005$ ). The percentage of heterogeneity between-studies not explained by sampling error (I2) was $98.6 \%$. The test for heterogeneity revealed $\mathrm{Q}(\mathrm{df}=24)=1600$, with a $\mathrm{P}$-value of 0.001 , showing significant heterogeneity among the studies. The $\mathrm{R}$ program meta created a more reasonable prediction interval ranging from $10 \%$ to 61 percent. This range shows the prehypertension prevalence rates that future investigations in Nigeria might uncover.

\section{Analysis of Between Study Heterogeneity}

\section{- Outliers and Influencers}

An investigation of likely outliers and influencers was conducted to explain the significant variation. Figure 6 displays the model's radial plot, which reveals no noticeable outliers. The influence analysis plots in Figure 7 corroborate this.

\section{- Gosh Analysis}

The probability of clusters within the included studies was investigated using the metafor R package's Gosh analysis. There are no clusters in Figure 8. The included studies did, in fact, form a single cluster with significant heterogeneity.

\section{- Meta-regression using Studies Characteristics as Predictors}

The geography of the study was used as the sole predictor, followed by the region, settlement, mean age, and sample size of the included studies. $\mathrm{Tau}^{2}$ declined from 0.017 in the model without predictors to 0.002 in the model with predictors (a 91\% drop). The change in $\mathrm{I}^{2}$ is also considerable, going from $98.6 \%$, which indicates significant heterogeneity, to 70.3 percent, which indicates moderate heterogeneity. This suggests that differences in study characteristics account for the majority of the heterogeneity between studies. Figure 9 shows the relative changes in the two heterogeneity metrics after fitting the meta-regression models.

\section{Analysis of Publication Bias}

The funnel plot of the model is shown in Figure 10. In the plot, there was no noticeable imbalance. The visual assessment of the funnel plot was confirmed by a formal test for plot asymmetry (regression test), which was not statistically significant ( $\mathrm{P}$ value $=$ 0.079).

\section{Sex-Specific Prevalence of Prehypertension in Nigeria}

As seen in Figure 11, males had a higher prehypertension prevalence of $39.1 \% \quad(95 \% \mathrm{CI}$ : $30.9 \%-47.6 \%$ ) than females, with a prevalence of $28.5 \%$ (95\% CI: $21.2 \%-36.4 \%$ ). The difference was not statistically significant $(\mathrm{P}=0.066)$.

\section{Prevalence of Prehypertension in Nigeria by Geo- political Region}

Figure 12 shows the prevalence of prehypertension in Nigeria by geopolitical zones. The North-East had the lowest prevalence of prehypertension, at $18 \%$. The North-West, with a prevalence of $43 \%$, had the highest rate of prehypertension. The model's $\mathrm{P}$ value is 0.003 , showing a statistically significant variation in prehypertension prevalence among the six geopolitical regions.

\section{Difference in Prevalence of Prehypertension between Urban and Rural Settlements in Nigeria}

The pooled prevalence in rural settings was $32 \%$, while the pooled prevalence in urban settings was $37 \%$, as shown in Figure 13. The difference $(\mathrm{P}=$ 0.307 ) was not statistically significant. 
Articles identified through database searching
Additional records identified through other sources $(\mathrm{n}=0)$

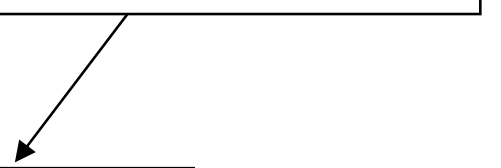

Records after duplicates removed $(\mathrm{n}=2906)$
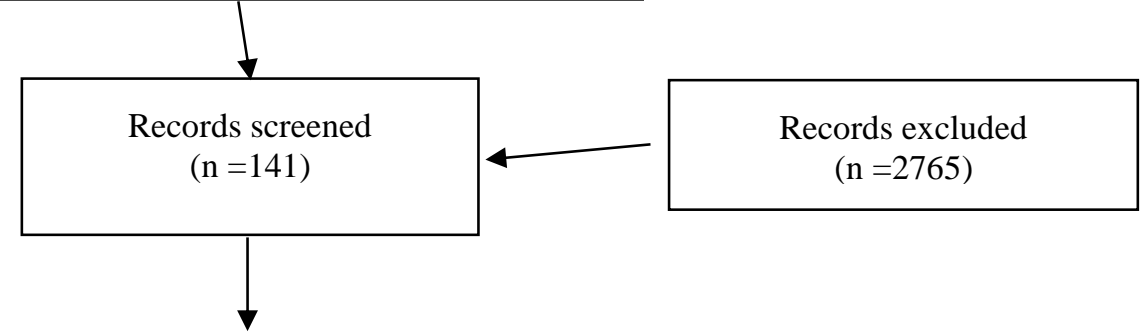

Full-text articles assessed for eligibility $(n=63)$
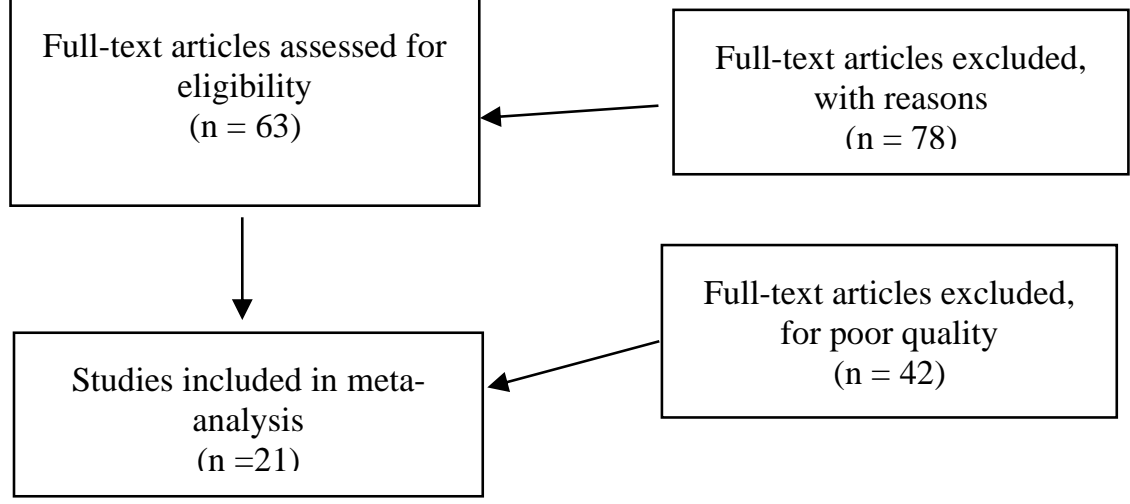

Full-text articles excluded, for poor quality $(n=42)$

Figure 2. Results of the Search Strategy

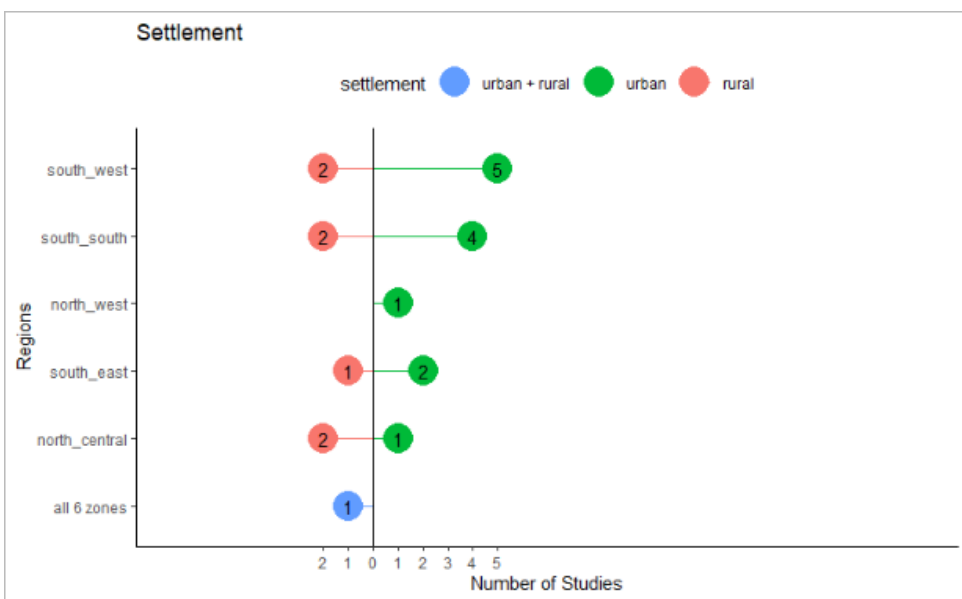

Figure 3. Number of Included Studies by Region and Settlement 
Bashir, M.A. et al.
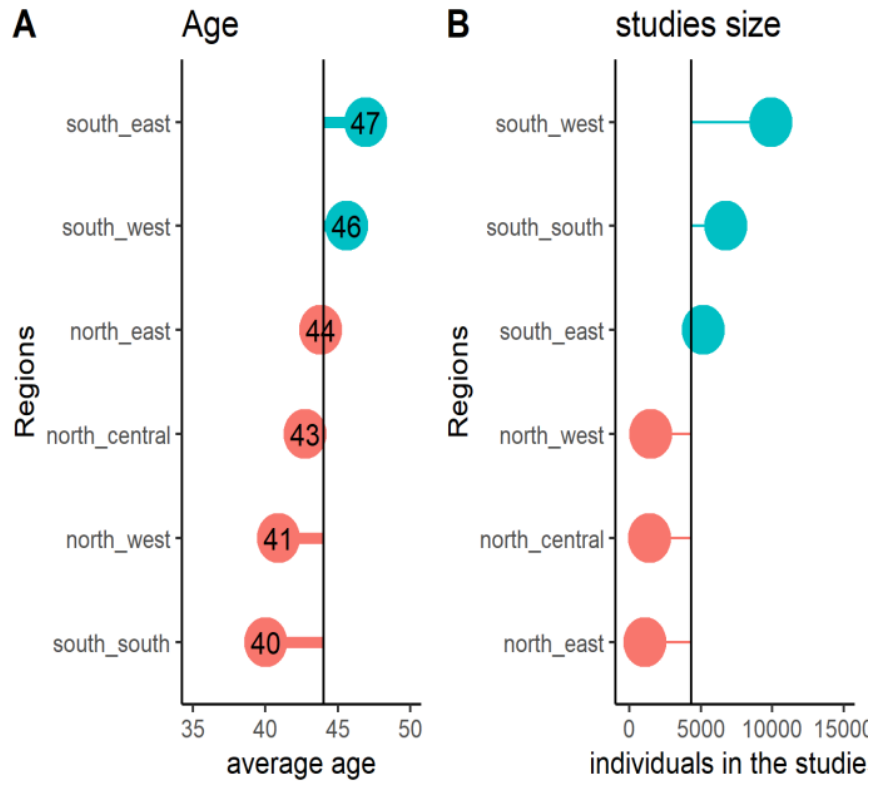

Figure 4. Mean Age and Number of Subjects in the Included Studies by Region

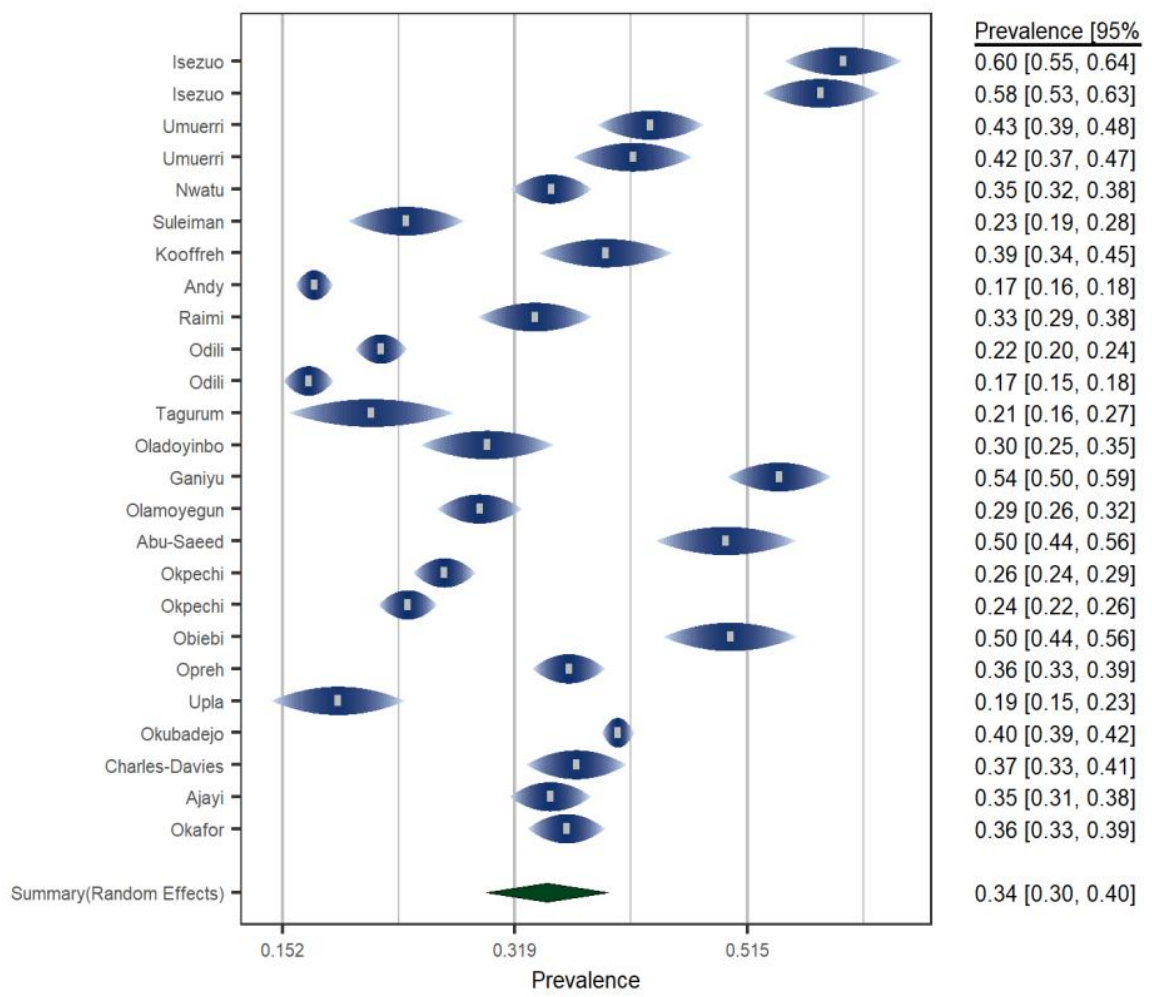

Figure 5. Forest plot 


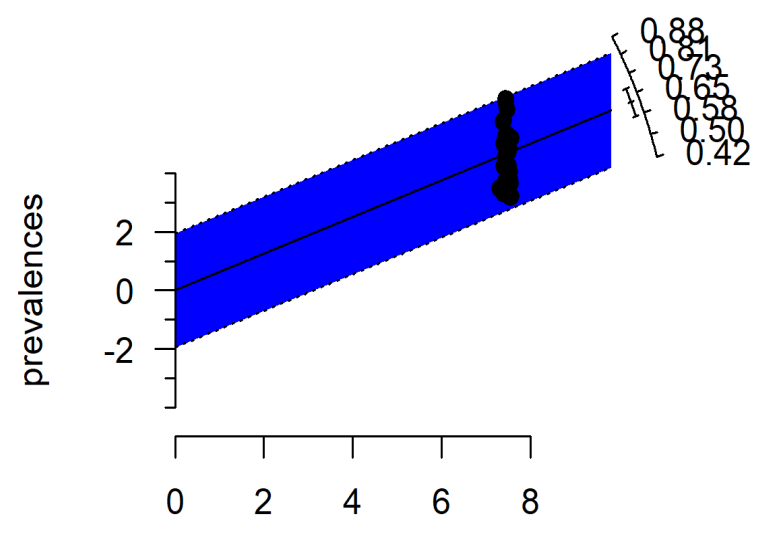

studies weights

Figure 6. Radial plot of the model
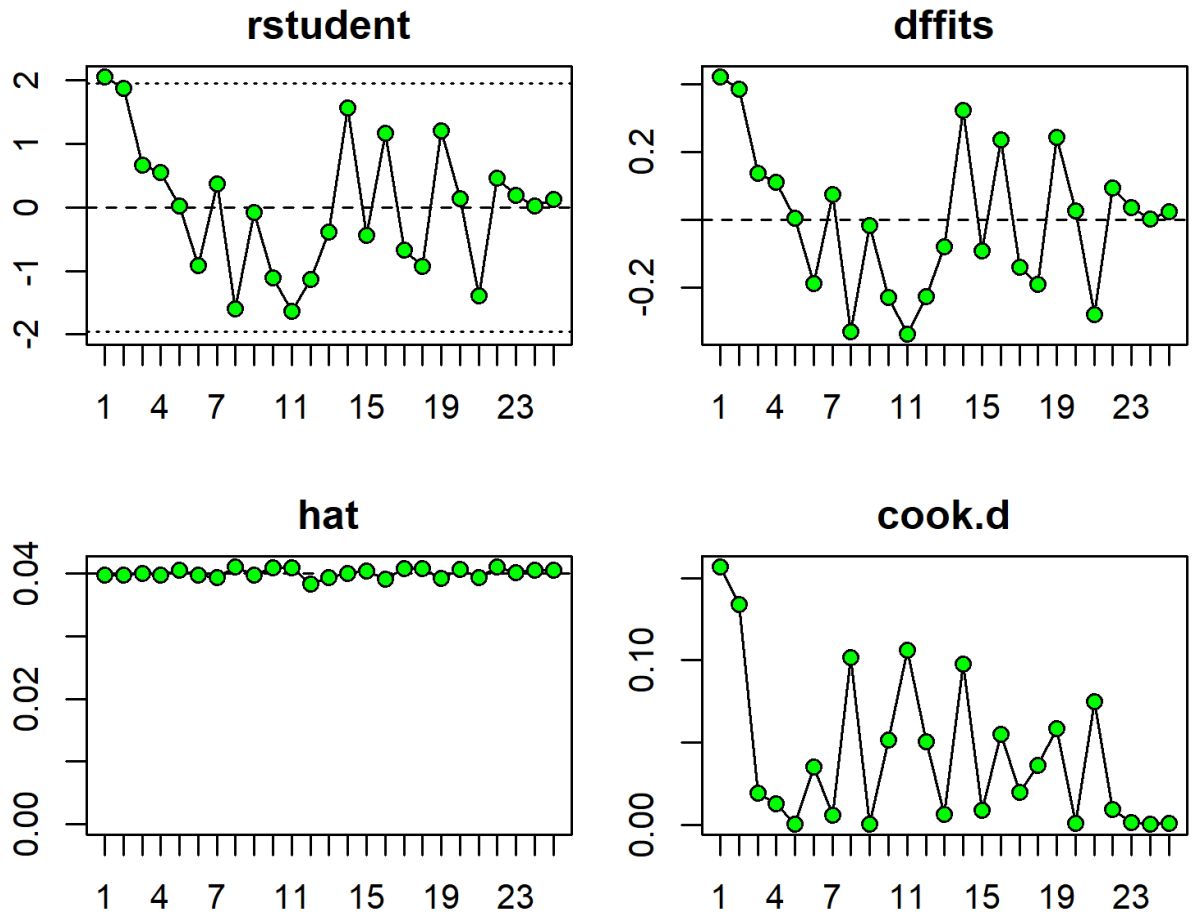

Figure 7. Influence analysis of the model 
Bashir, M.A. et al.

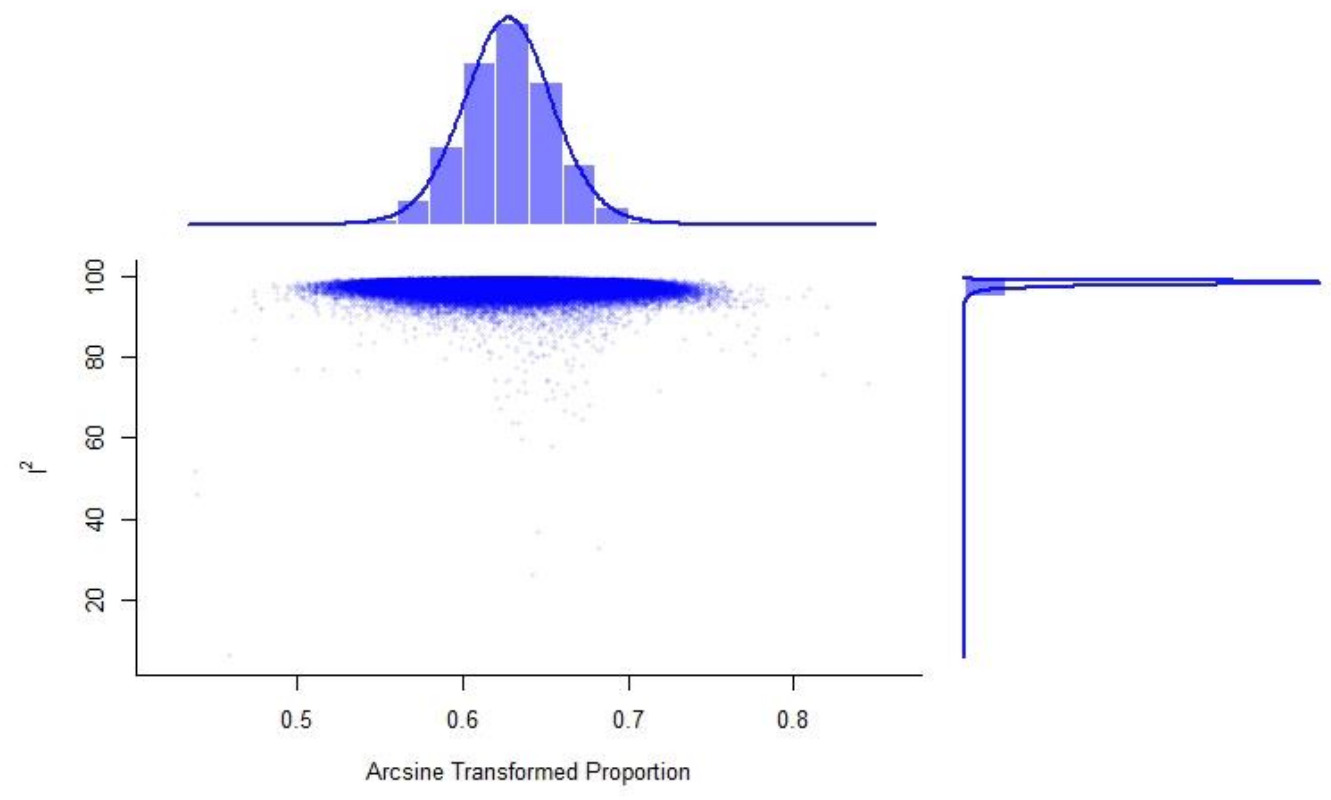

Figure 8. Gosh Plot of the Model

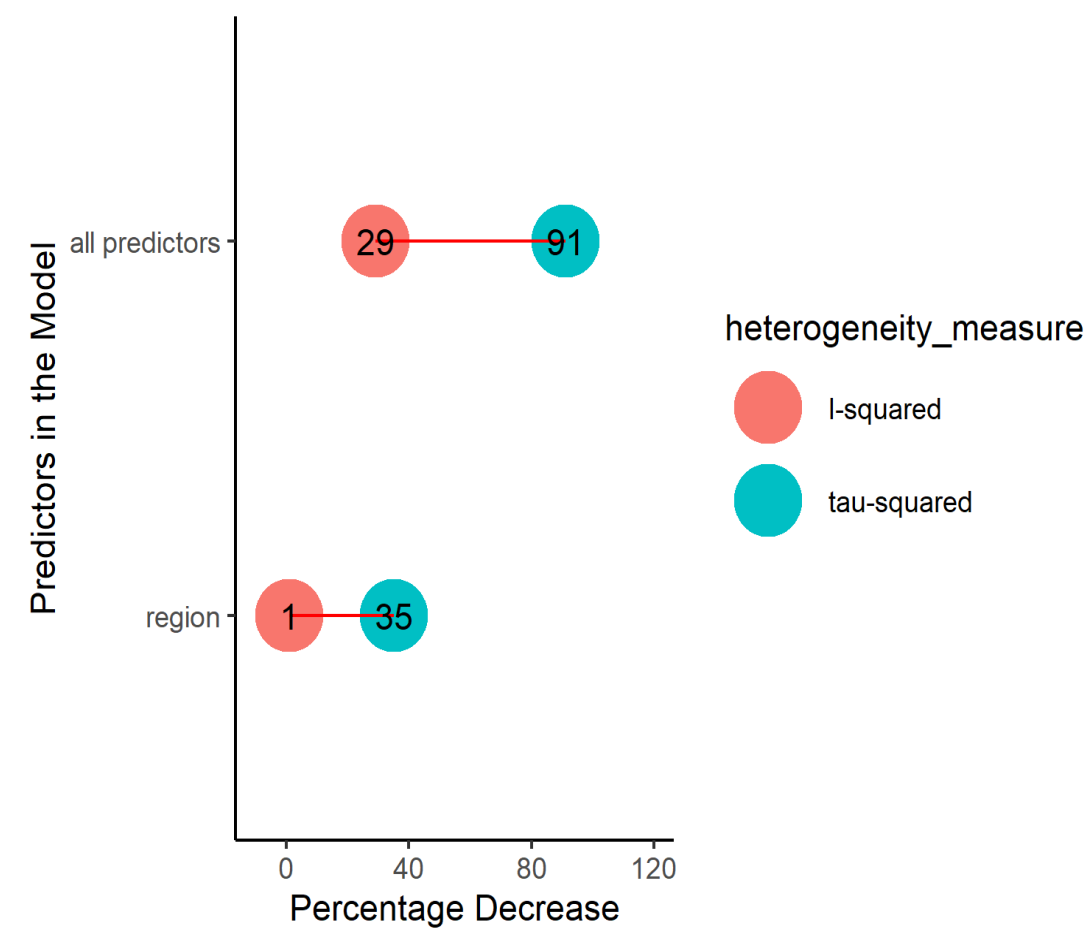

Figure 9. Comparison of Change in the Heterogeneity Measures after Fitting Meta-regression Models 


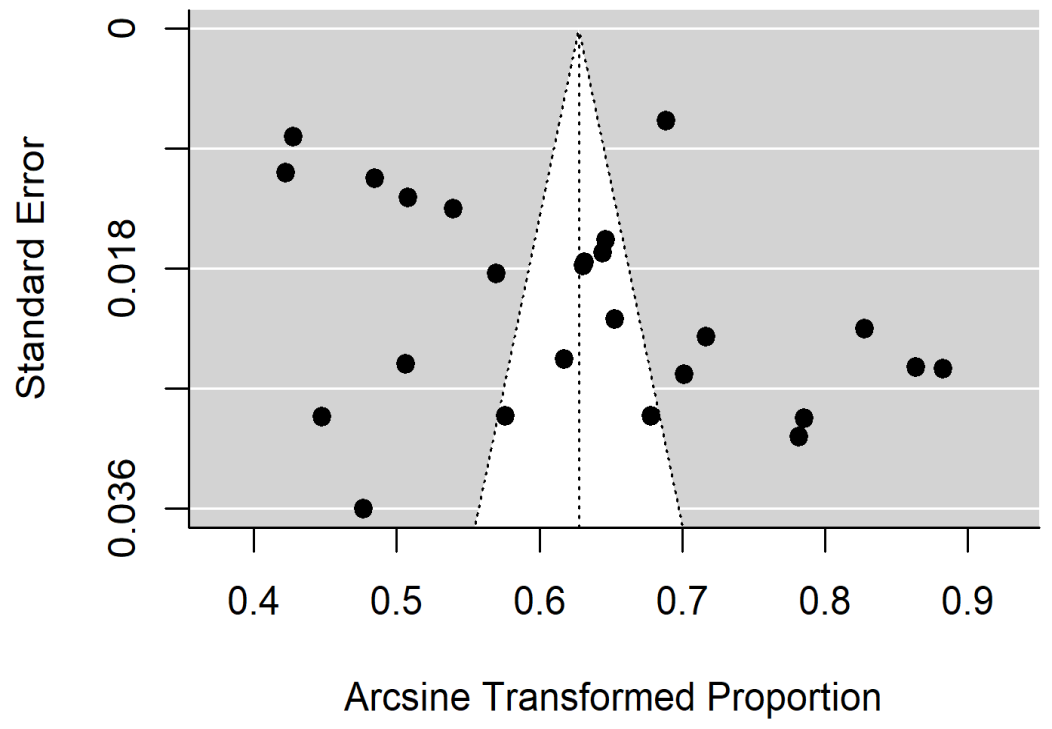

Figure 10. Funnel Plot

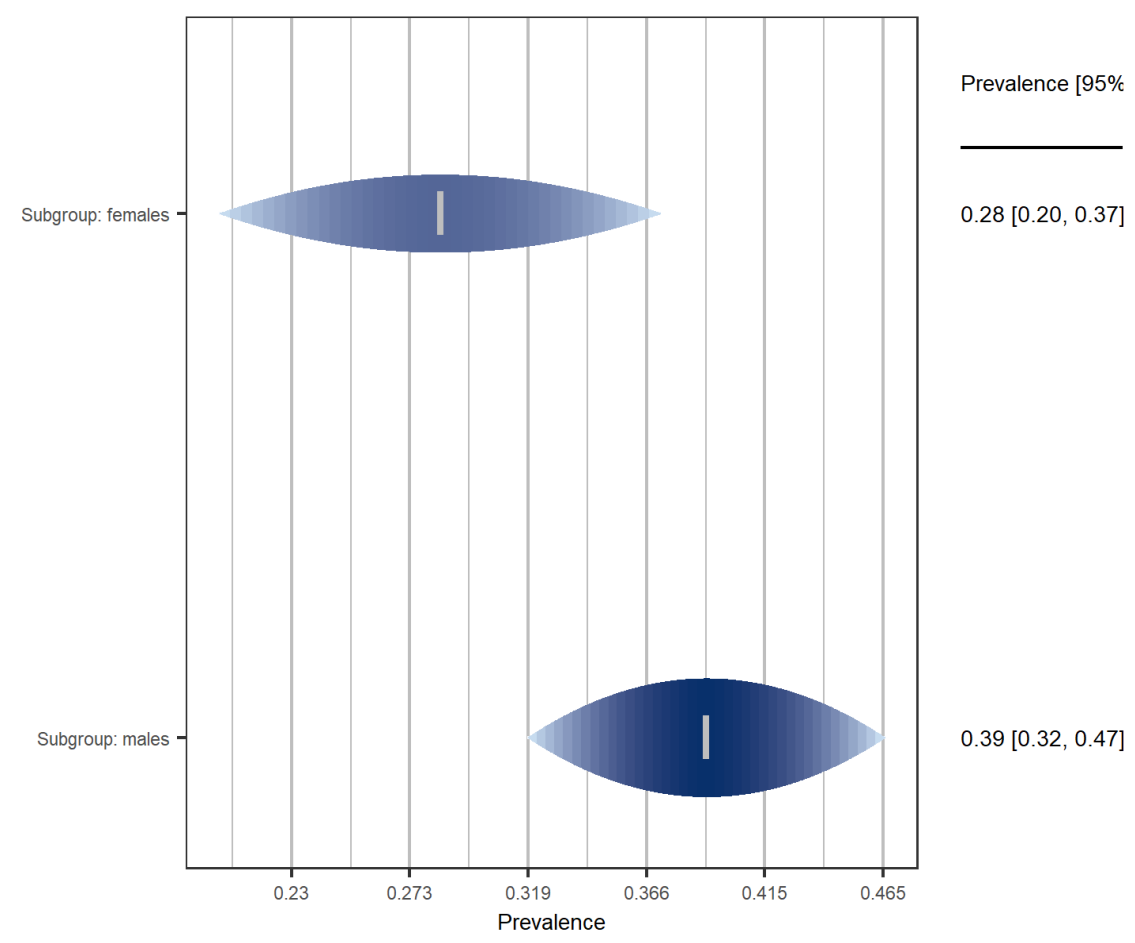

Figure 11. Prevalence of Prehypertension in Males and Females 

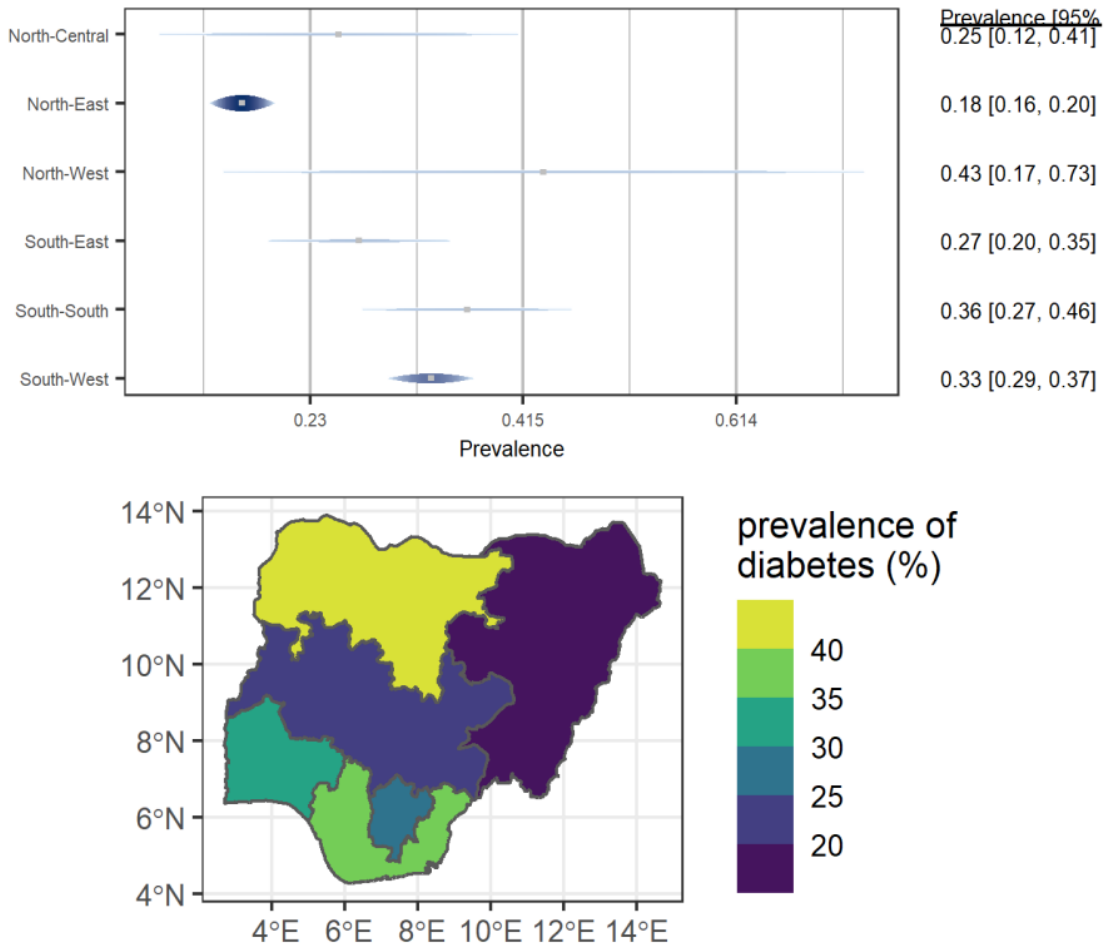

Figure 12. Forest Plot and Map of prevalence of Prehypertension by region

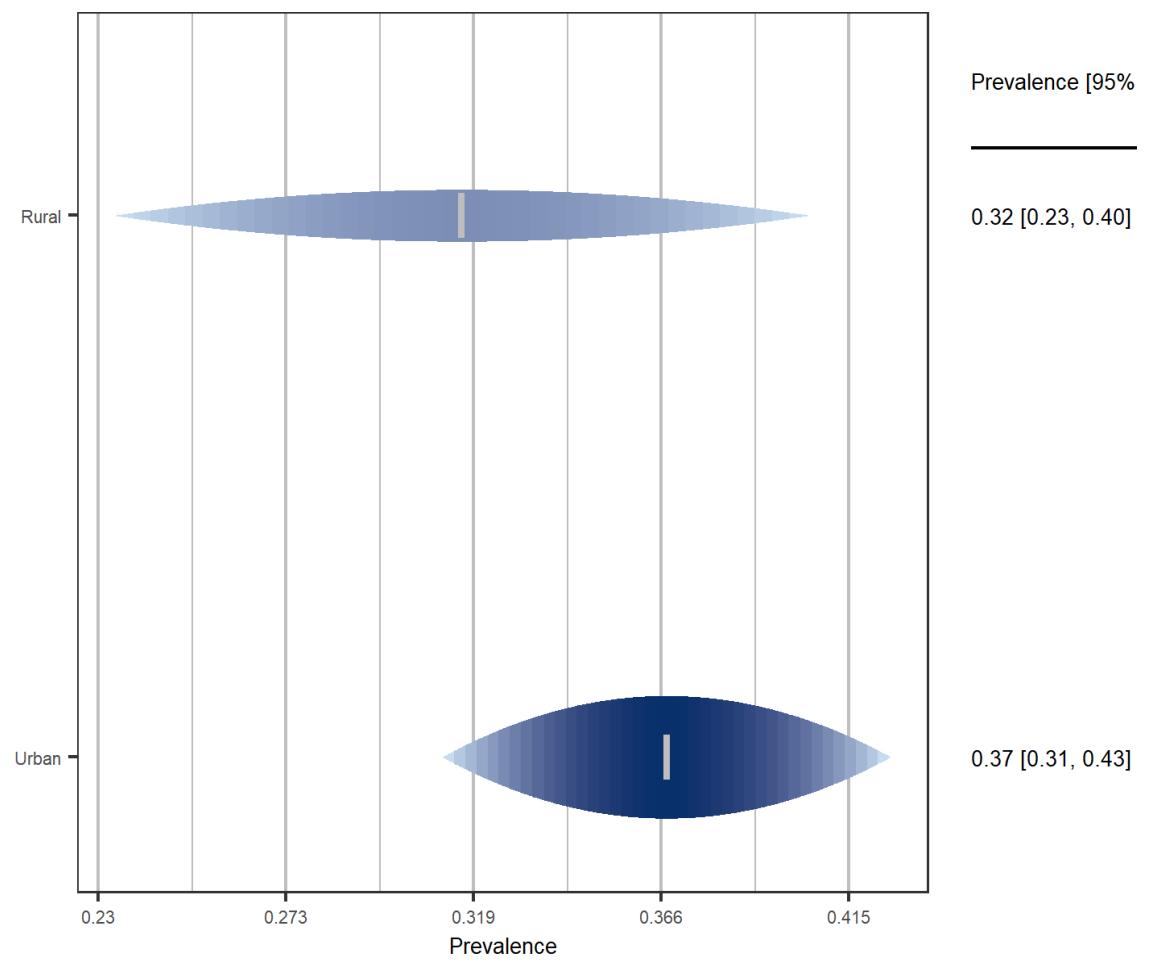

Figure 13. Forest plot of prevalence by rural and urban settlements

Table 2. Characteristics of studies with quality appraisal results 
Prehypertension in Nigeria: A meta-analysis

\begin{tabular}{|c|c|c|c|c|c|c|c|c|c|c|c|c|c|}
\hline \multirow[b]{2}{*}{ 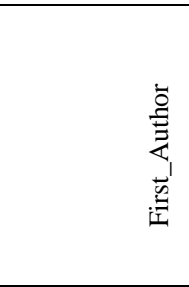 } & \multirow[b]{2}{*}{ 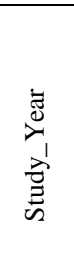 } & \multirow[b]{2}{*}{ 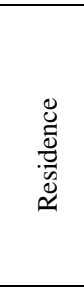 } & \multirow[b]{2}{*}{ State } & \multirow[b]{2}{*}{ Region } & \multirow[b]{2}{*}{ 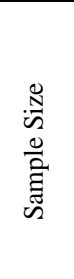 } & \multicolumn{6}{|c|}{ Scoring Items } & \multirow[b]{2}{*}{ 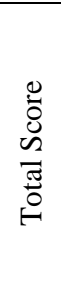 } & \multirow[b]{2}{*}{$\frac{\nexists 2}{3}$} \\
\hline & & & & & & 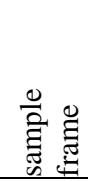 & 告 & 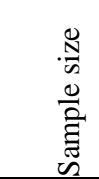 & 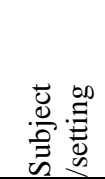 & 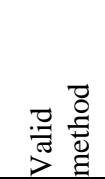 & 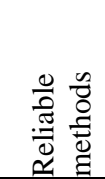 & & \\
\hline Isezuo $^{18}$ & 2011 & urban & Sokoto & North_West & 782 & 1 & 1 & 1 & 1 & 1 & 1 & 6 & Good \\
\hline Okafor ${ }^{19}$ & 2011 & urban & Enugu & South_East & 898 & 1 & 1 & 1 & 1 & 1 & 1 & 6 & Good \\
\hline Wokoma ${ }^{20}$ & 2011 & rural & Rivers & South_South & 152 & 0 & 0 & 0 & 1 & 1 & 1 & 3 & Poor \\
\hline Andy ${ }^{21}$ & 2012 & rural & $\begin{array}{l}\text { Akwa Ibom } \\
\text { and Cross } \\
\text { rivers }\end{array}$ & South_South & 3869 & 1 & 0 & 1 & 1 & 1 & 1 & 5 & Good \\
\hline Nwazor 22 & 2012 & urban & Ebonyi & South_East & 215 & 0 & 0 & 0 & 1 & 1 & 1 & 3 & Poor \\
\hline Adejumo $^{23}$ & 2013 & urban & Lagos & South_West & 300 & 0 & 0 & 0 & 1 & 1 & 1 & 3 & Poor \\
\hline $\begin{array}{l}\text { Charles-Davies } \\
24\end{array}$ & 2013 & urban & Ibadan & South_West & 534 & 1 & 1 & 1 & 1 & 1 & 0 & 5 & Good \\
\hline Makusidi ${ }^{25}$ & 2013 & urban & Sokoto & North_West & 535 & 0 & 0 & 1 & 1 & 1 & 1 & 4 & Poor \\
\hline Okpechi ${ }^{26}$ & 2013 & urban & Abia & South_East & 2983 & 1 & 1 & 1 & 1 & 1 & 1 & 6 & Good \\
\hline Suleiman ${ }^{27}$ & 2013 & urban & Bayelsa & South_South & 400 & 1 & 1 & 1 & 1 & 1 & 1 & 6 & Good \\
\hline $\mathrm{Abah}^{28}$ & 2014 & urban & Plateu & North_Central & 200 & 0 & 0 & 0 & 1 & 0 & 1 & 2 & Poor \\
\hline Abu-Saeed ${ }^{29}$ & 2014 & urban & Kwara & North_Central & 270 & 1 & 1 & 0 & 1 & 1 & 1 & 5 & Good \\
\hline Adamu $^{30}$ & 2014 & urban & Sokoto & North_West & 298 & 0 & 0 & 0 & 1 & 1 & 1 & 3 & Poor \\
\hline $\mathrm{Ale}^{31}$ & 2014 & urban & Lagos & South_West & 101 & 0 & 0 & 0 & 1 & 1 & 1 & 3 & Poor \\
\hline Ganiyu $^{32}$ & 2014 & rural & Delta & South_South & 500 & 1 & 1 & 1 & 1 & 1 & 0 & 5 & Good \\
\hline Okafor $^{33}$ & 2014 & rural & Anambra & South_East & 137 & 0 & 0 & 0 & 1 & 1 & 1 & 3 & Poor \\
\hline Egbuonu $^{34}$ & 2015 & urban & Abia & South_East & 200 & 0 & 0 & 0 & 1 & 1 & 0 & 2 & Poor \\
\hline Egbi $^{35}$ & 2015 & urban & Bayelsa & South_South & 231 & 0 & 0 & 0 & 1 & 1 & 1 & 3 & Poor \\
\hline Guwatudde ${ }^{36}$ & 2015 & urban & Abuja & North_Central & 163 & 0 & 0 & 0 & 1 & 1 & 1 & 3 & Poor \\
\hline Okwounu $^{37}$ & 2015 & urban & Abia & South_East & 389 & 0 & 0 & 1 & 1 & 1 & 1 & 4 & Poor \\
\hline Oladoyinbo ${ }^{38}$ & 2015 & urban & Ogun & South_West & 300 & 1 & 1 & 0 & 1 & 1 & 1 & 5 & Good \\
\hline Tagurum ${ }^{39}$ & 2015 & rural & Plateu & North_Central & 195 & 1 & 1 & 0 & 1 & 1 & 1 & 5 & Good \\
\hline Uwah $^{40}$ & 2015 & urban & Akwa Ibom & South_South & 393 & 0 & 0 & 1 & 1 & 1 & 1 & 4 & Poor \\
\hline Adeoye ${ }^{41}$ & 2016 & urban & Ibadan & South_West & 352 & 0 & 0 & 1 & 1 & 1 & 1 & 4 & Poor \\
\hline Ajayi ${ }^{42}$ & 2016 & urban & Ibadan & South_West & 806 & 1 & 1 & 1 & 1 & 1 & 1 & 6 & Good \\
\hline Ayanniyi ${ }^{43}$ & 2016 & urban & Not reported & South_West & 356 & 0 & 0 & 1 & 1 & 1 & 1 & 4 & Poor \\
\hline Kooffreh ${ }^{44}$ & 2016 & urban & Cross river & South_South & 300 & 1 & 1 & 0 & 1 & 1 & 1 & 5 & Good \\
\hline Mmom $^{45}$ & 2016 & urban & Rivers & South_South & 201 & 0 & 0 & 0 & 1 & 1 & 0 & 2 & Poor \\
\hline Olamoyegun ${ }^{46}$ & 2016 & urban & Ekiti & South_West & 750 & 1 & 1 & 1 & 1 & 1 & 1 & 6 & Good \\
\hline Ononamadu $^{47}$ & 2016 & mixed & Anambra & South_East & 912 & 0 & 0 & 1 & 1 & 1 & 1 & 4 & Poor \\
\hline Aladeniyi ${ }^{48}$ & 2017 & urban & Ondo & South_West & 4844 & 0 & 0 & 1 & 1 & 1 & 1 & 4 & Poor \\
\hline Ayodele ${ }^{49}$ & 2017 & urban & Osun & South_West & 131 & 0 & 0 & 0 & 1 & 1 & 1 & 3 & Poor \\
\hline Ejike $^{50}$ & 2017 & urban & Mixed & South_East & 1610 & 0 & 0 & 1 & 1 & 1 & 1 & 4 & Poor \\
\hline
\end{tabular}


Bashir, M.A. et al.

\begin{tabular}{|c|c|c|c|c|c|c|c|c|c|c|c|c|c|}
\hline Nwatu ${ }^{51}$ & 2017 & rural & Enugu & South_East & 824 & 1 & 1 & 1 & 1 & 1 & 1 & 6 & Good \\
\hline${ }_{52}$ Ambakederemo & 2018 & urban & Bayelsa & South_South & 168 & 0 & 0 & 0 & 1 & 1 & 1 & 3 & Poor \\
\hline Bello-Ovosi $^{53}$ & 2018 & urban & Kaduna & North_West & 181 & 0 & 0 & 0 & 1 & 1 & 1 & 3 & Poor \\
\hline Dokunmu $^{54}$ & 2018 & urban & Ogun & South_West & 182 & 0 & 0 & 0 & 1 & 1 & 1 & 3 & Poor \\
\hline Egbi $^{55}$ & 2018 & rural & Bayelsa & South_South & 131 & 0 & 0 & 0 & 1 & 1 & 1 & 3 & Poor \\
\hline Ibuaku $^{56}$ & 2018 & rural & Delta & South_South & 432 & 0 & 0 & 1 & 1 & 1 & 0 & 3 & Poor \\
\hline Nkechi ${ }^{57}$ & 2018 & urban & Rivers & South_South & 304 & 0 & 0 & 1 & 1 & 1 & 1 & 4 & Poor \\
\hline Ofori $^{58}$ & 2018 & rural & Rivers & South_South & 389 & 0 & 0 & 1 & 1 & 1 & 1 & 4 & Poor \\
\hline Olatona ${ }^{59}$ & 2018 & urban & Lagos & South_West & 503 & 0 & 0 & 1 & 1 & 1 & 0 & 3 & Poor \\
\hline Shittu ${ }^{60}$ & 2018 & $\begin{array}{l}\text { urban } \\
+ \\
\text { rural }\end{array}$ & Oyo & South_West & 6915 & 0 & 0 & 1 & 1 & 1 & 1 & 4 & Poor \\
\hline Wordu ${ }^{61}$ & 2018 & urban & Rivers & South_South & 215 & 1 & 0 & 0 & 1 & 1 & 1 & 4 & Poor \\
\hline Adelowo ${ }^{62}$ & 2019 & urban & Abuja & North_Central & 417 & 0 & 0 & 1 & 1 & 0 & 0 & 2 & Poor \\
\hline Adenrele ${ }^{63}$ & 2019 & urban & Abuja & North_Central & 417 & 0 & 0 & 0 & 1 & 0 & 0 & 1 & Poor \\
\hline Ajayi ${ }^{64}$ & 2019 & urban & Ekiti & South_West & 426 & 0 & 0 & 1 & 1 & 0 & 0 & 2 & Poor \\
\hline Obiebi ${ }^{65}$ & 2019 & urban & Delta & South_South & 296 & 1 & 1 & 0 & 1 & 1 & 1 & 5 & Good \\
\hline Okubadejo $^{66}$ & 2019 & urban & Lagos & South_West & 5365 & 1 & 1 & 1 & 1 & 1 & 1 & 6 & Good \\
\hline Yakubu ${ }^{67}$ & 2019 & urban & All 36 states & $\begin{array}{l}\text { all the six geo- } \\
\text { political zones }\end{array}$ & 3013 & 1 & 1 & 1 & 1 & 0 & 0 & 4 & Poor \\
\hline Banigbe $^{68}$ & 2020 & $\begin{array}{l}\text { urban } \\
+ \\
\text { rural }\end{array}$ & Benue & North_Central & 6538 & 0 & 0 & 1 & 1 & 1 & 0 & 3 & Poor \\
\hline Dada ${ }^{69}$ & 2020 & urban & Ekiti & South_West & 300 & 0 & 0 & 0 & 1 & 1 & 1 & 3 & Poor \\
\hline Odili 70 & 2020 & $\begin{array}{l}\text { urban } \\
+ \\
\text { rural }\end{array}$ & 6 states & all 6 zones & 4192 & 1 & 1 & 1 & 1 & 1 & 1 & 6 & Good \\
\hline Odunaiya $^{71}$ & 2020 & urban & Ibadan & South_West & 316 & 0 & 0 & 0 & 1 & 1 & 1 & 3 & Poor \\
\hline Olaitan ${ }^{72}$ & 2020 & urban & Plateu & North_Central & 283 & 0 & 0 & 0 & 1 & 1 & 0 & 2 & Poor \\
\hline Olawade $^{73}$ & 2020 & rural & Gombe & North_East & 78 & 0 & 0 & 0 & 1 & 1 & 0 & 2 & Poor \\
\hline Raimi $^{74}$ & 2020 & rural & Ogun & South_West & 412 & 1 & 0 & 1 & 1 & 1 & 1 & 5 & Good \\
\hline Umuerri ${ }^{75}$ & 2020 & urban & Delta & South_South & 852 & 1 & 0 & 1 & 1 & 1 & 1 & 5 & Good \\
\hline Upla $^{76}$ & 2020 & rural & Nasarawa & North_Central & 299 & 1 & 1 & 1 & 1 & 1 & 1 & 6 & Good \\
\hline Wada $^{77}$ & 2020 & rural & Osun & South_West & 138 & 0 & 0 & 0 & 1 & 1 & 0 & 2 & Poor \\
\hline Opreh $^{78}$ & 2021 & rural & Osun & South_West & 1012 & 1 & 1 & 1 & 1 & 1 & 1 & 6 & Good \\
\hline
\end{tabular}




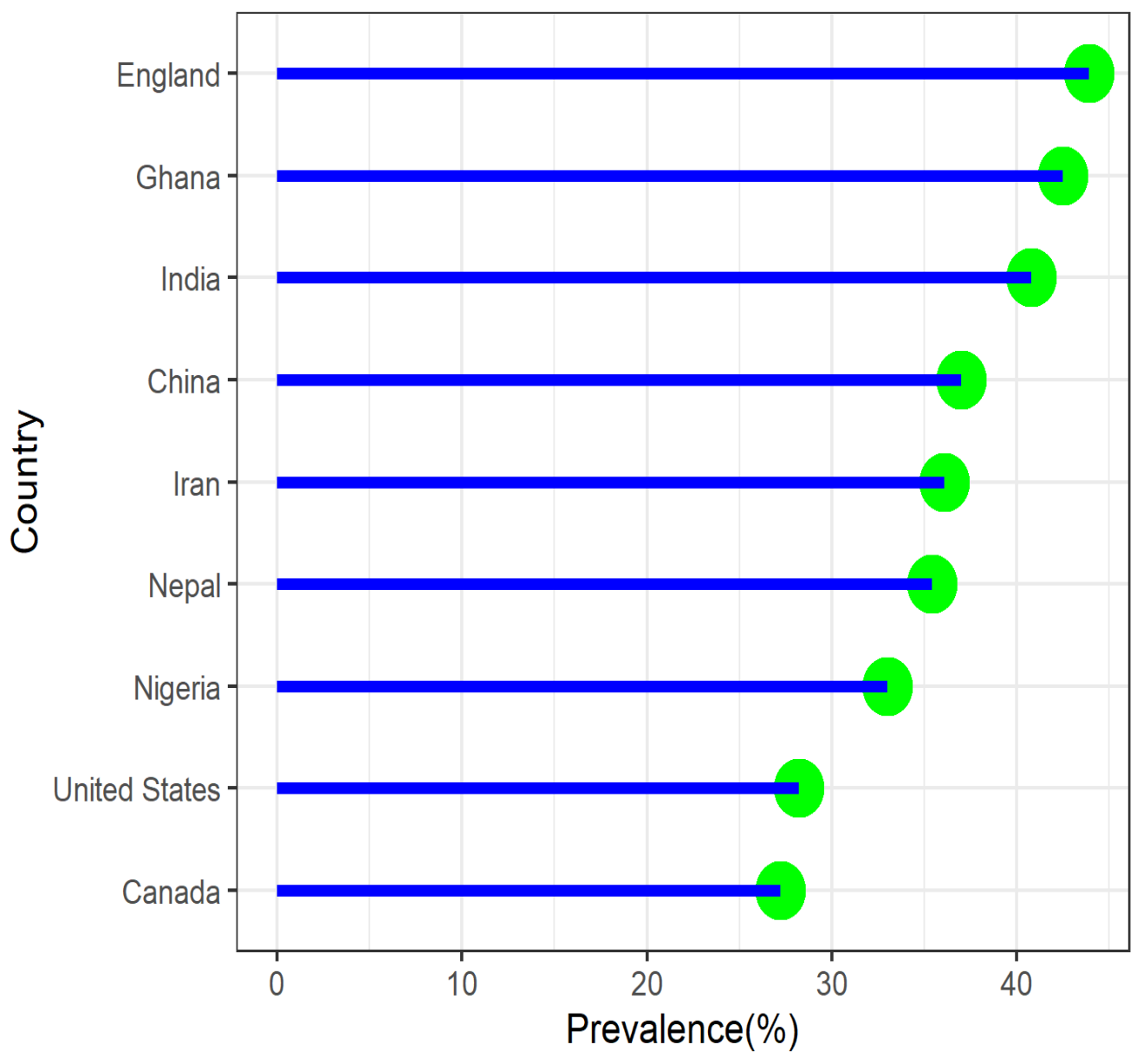

Figure 14. Prevalence of Prehypertension in Selected Countries 


\section{Discussion}

This study's pooled estimate of prehypertension prevalence in Nigeria, 34\% (95\% CI: $30-40 \%$ ), is close to but more precise than a recent meta-analysis in the country, which reported a prevalence of $30.9 \%$ (95\% CI: 22.0-39.7\%) (6). The difference in precision between the two meta-analyses can be explained by the difference in the number of studies and individuals included in each; our analysis includes a larger number of studies and individuals, which explains our estimate's higher precision. It's worth noting that prehypertension and hypertension have nearly identical prevalence rates (6). This indicates that twothirds of adult Nigerians have high blood pressure and are at a high risk of acquiring end-stage cardiovascular events such as stroke, coronary heart disease, and chronic kidney disease.

The two measures of heterogeneity, $\mathrm{I}^{2}$ and tau ${ }^{2}$, show different behaviors in this study's analysis of heterogeneity. The former is known to be sensitive to study size, i.e., if the included studies are quite large, the sampling error will be near to zero, and the $\mathrm{I} 2$ ratio will approach $100 \%$. (79). The minimal sample size required to measure the prehypertension prevalence of $34 \%$ found in this study with a precision of 0.05 and a 95\% confidence interval was 345 . (10). The papers included in this meta-analysis are relatively large, according to the selection criteria, with an interquartile range of 635 for sample sizes. As a result, even if the between-study heterogeneity is not significant, $\mathrm{I}^{2}$ may be closer to 100 percent. This is most likely the case because a metaregression with a single predictor (the region where the study was conducted) reduced tau ${ }^{2}$ by $35 \%$ while leaving $\mathrm{I}^{2}$ unchanged (Figure 9 ).

Prehypertension is more common in Nigeria than in the United States (80) and Canada (81), equivalent to what was discovered in China (82), Iran (83), and Nepal (84) and lower than in Ghana (85), India (86), and England (81). (Figure 14).

The findings of this study, a higher prevalence of prehypertension in males than females $39.1 \%$ vs. $28.5 \%$ ), are consistent with a global trend identified in another meta-analysis of published research from around the world (5). Males had a greater prevalence rate of prehypertesion in Nepal (31.6\% vs $20.0 \%$ ) (84), India (47.3\% vs $35.1 \%$ ) (86), England (53.5\% vs $35 \%$ ), Canada (32.9\% vs $21.6 \%$ ), and the United Kingdom (32.9\% vs $21.6 \%$ ).

In Nigeria, the higher incidence of prehypertension in urban settlements (32\% vs. 37\%) contrasts with findings from a nationwide study conducted in 2017, which revealed a higher prevalence of prehypertension in rural regions (37.5\% vs. $24.7 \%$ ) (70). The survey's findings are credible under this meta-analytic paradigm, given the overlapping confidence ranges of the pooled prevalence in rural and urban areas (24$39 \%$ and $30-44 \%$, respectively). This high prevalence in rural regions may be a result of Nigerian rural areas' urbanization, with the adoption of lifestyles causing an increase in non-communicable diseases (70). Prehypertension was found to be more common in rural regions than in urban areas in Nepal $(40.4 \%$ vs $29.3 \%$ ) (23) and India (41.3\% vs $40.2 \%$ ). (86).

The three geopolitical regions in the country with the highest prevalence of prehypertension, in descending order, were the North-West (43\%), the South-South $(36 \%)$, and the South-West (33\%), with the North-East having the lowest prevalence rate among the six $(18 \%)$. Only the prevalence estimates in the SouthWest and North-East had a limited confidence interval, while the estimates in the remaining regions had wide confidence intervals (Figure 12). The SouthWestern and South-Southern regions' high rankings are identical to the national poll described above (70).

\section{Conclusion}

Prehypertension affects $34 \%$ of adult Nigerians (95\% confidence interval: $30 \%-40 \%$ ), or 41.4 million people. Males had a $39.1 \%$ (95\% CI: 30.9-47.6\%) higher prevalence of prehypertension than females, who had a frequency of $28.5 \%$ (95\% CI: $21.2-36.4 \%$ ). The North-East has the lowest prevalence of prehypertension, at $18 \%$. The North-West, with a prevalence of $43 \%$, had the highest rate of prehypertension. Rural areas had a pooled prevalence rate of $32 \%$, whereas urban settlements had a combined prevalence of $37 \%$. There were no statistically significant differences between the sexes or between rural and urban communities. Differences between geopolitical regions, on the other hand, were statistically significant. In conclusion, Nigeria has a significant prevalence of prehypertension, which poses a future risk of hypertension and other cardiovascular problems.

\section{References}

1. Whelton, P.K., Carey, R.M., Aronow, W.S., Casey, D.E., Collins, K.J., Hilmmelfarb C.D., et al. 2017 ACC/AHA/AAPA/ABC/ACPM/AGS/APhA/ASH/A SPC/NMA/PCNA Guideline for the Prevention, Detection, Evaluation, and Management of High Blood Pressure in Adults: A Report of the American College of Cardiology/American Heart Association Task Force on Clinical Practice Guidelines. Hypertension 2018;71:e13-115.

2. National High Blood Pressure Education Program. The Seventh Report of the Joint National Committee on Prevention, Detection, Evaluation, and Treatment 
of High Blood Pressure. Bethesda (MD): National Heart, Lung, and Blood Institute (US); 2004. Report No. 04-5230. Available from: http://www.ncbi.nlm.nih.gov/books/NBK9630/. 3. Vasan, R.S., Larson, M.G., Leip, E.P., Kannel, W.B., Levy, D. Assessment of frequency of progression to hypertension in non-hypertensive participants in the Framingham Heart Study: A cohort study. Lancet 2001;358(9294):1682-6.

4. NCD Risk Factor Collaboration (NCD-RisC). Worldwide trends in blood pressure from 1975 to 2015: A pooled analysis of 1479 population-based measurement studies with $19 \cdot 1$ million participants. Lancet 2017;389(10064):37-55.

5. Guo, X., Zhang, X., Hu, J., Sun, Y., Zheng, L., Zou, L., et al. The prevalence and heterogeneity of prehypertension: A meta-analysis and meta-regression of published literature worldwide. Cardiovasc J Afr 2012;23(1):44-50.

6. Adeloye, D., Owolabi, E.O., Ojji, D.B., Auta, A., Dewan, M.T., Olanrewaju, T.O., et al. Prevalence, awareness, treatment, and control of hypertension in Nigeria in 1995 and 2020: A systematic analysis of current evidence. J Clin Hypertens 2021;23(5):963977.

7. Udo, K.R., Ajayi, J.F.A., Kirk-Greene, A.H.M., Falola, T.O. Nigeria. Encyclopedia Britannica. 2020 [Accessed on 2021, July $5^{\text {th }}$; Available from: https://www.britannica.com/place/Nigeria.

8. UNFPA - United Nations Population Fund. UNFPA - United Nations Population Fund. 2021 [Accessed on 2021, July $5^{\text {th }}$. Available from: https://www.unfpa.org/.

9. Joanna Briggs Institute. Joanna Briggs Institute Critical Appraisal Checklist for Prevalence Studies. Joanna Briggs Institute; 2017. Available from: https://jbi.global/sites/default/files/2019-

05/JBI_Critical_Appraisal-

Checklist_for_Prevalence_Studies2017_0.pdf.

10. EPITOOLS. Epitools - Sample size to estimate a proportion or apparent prevalence with specified precision. [Accessed on 2021, July $28^{\text {th }}$ ]. Available from: https://epitools.ausvet.com.au/oneproportion.

11. R Core Team. R: A language and environment for statistical computing. Vienna, Austria: R Foundation for Statistical Computing; 2021 [Accessed on 2021, June $16^{\text {th }}$. Available from: https://www.r-project.org/. 12. Viechtbauer, W. Conducting meta-analyses in with the metafor package. J Stat Soft 2010;36(3):1-48. Available from: https://doi.org/10.18637/jss.v036.i03. 13. Sidik, K., Jonkman, J.N. On Constructing Confidence Intervals for a Standardized Mean Difference in Meta-analysis. Communications in Statistics - Simulation and Computation. 2003;32(4):1191-1203.
14. Viechtbauer, W., Cheung, M.W.-L. Outlier and influence diagnostics for meta-analysis. Res Synth Methods 2010;1(2):112-125.

15. Balduzzi, S., Rücker, G., Schwarzer, G. How to perform a meta-analysis with R: A practical tutorial. Evidence-Based Mental Health 2019;22:153-160.

16. Borenstein, M., Higgins, J.P.T., Hedges, L.V., Rothstein, H.R. Basics of meta-analysis: $I^{2}$ is not an absolute measure of heterogeneity: $I^{2}$ is not an absolute measure of heterogeneity. Res Synth Methods 2017;8(1):5-18.

17. Egger, M., Davey Smith, G., Schneider, M., Minder, C. Bias in meta-analysis detected by a simple, graphical test. BMJ 1997;315:629-634.

18. Isezuo, S.A., Sabir, A.A., Ohwovorilole, A.E., Fasanmade, O.A. Prevalence, associated factors and relationship between prehypertension and hypertension: A study of two ethnic African populations in Northern Nigeria. J Human Hypertens 2011;25:224-230.

19. Okafor, C.I., Fasanmade, O., Ofoegbu, E., Ohwovoriole, A.E. Comparison of the performance of two measures of central adiposity among apparently healthy Nigerians using the receiver operating characteristic analysis. Indian $\mathrm{J}$ Endocrinol Metab 2011;15(4):320-6.

20. Wokoma, F.S., Alasia, D.D. Blood Pressure Pattern in Barako-A Rural Community in Rivers State, Nigeria. Niger Health J 2011;11(1):8-13.

21. Andy, J.J., Peters, E.J., Ekrikpo, U.E., Akpan, N.A., Unadike, B.C., Ekott, .JU. Prevalence and correlates of hypertension among the Ibibio/Annangs, Efiks and Obolos: A cross sectional community survey in rural South-South Nigeria. Ethn Dis 2012;22(3):335-9. Available from: https://www.ethndis.org/edonline/index.php/ethndis/a rticle/view/459.

22. Nwazor, F.O.O., Oputa, S.C. Blood Pressure Pattern Among Young People In South-Eastern Nigeria: A Cross-Sectional Survey. Ebonyi Med J 2012;11(1-2):77-83.

23. Adejumo, E.N., Ogundahunsi, O.A., Adejumo, O.A., Daniel, O.J., Okafor, P.A., Azenabor, A. Generalized And Abdominal Obesity; The Association With Hypertension Among Men In Ikeja, Lagos State. Niger J Clin Med 2013;5(1).

24. Charles-Davies, M.A., Fasanmade, A.A., Olaniyi, J.A., Oyewole, O.E., Owolabi, M.O., Adebusuyi, J.R., et al. Metabolic Alterations in Different Stages of Hypertension in an Apparently Healthy Nigerian Population. Int J Hypertens 2013;2013:351357. 25. Makusidi, M.A., Liman, H.M., Yakubu, A., Isah, M.D.A., Jega, R.M., Adamu, H., et al. Prevalence of Non-communicable Diseases and its Awareness among Inhabitants of Sokoto Metropolis: Outcome of 
a Screening Program for Hypertension, Obesity, Diabetes Mellitus and Overt proteinuria. Arab J Nephrol Transplant 2013;6(3):189-91.

26. Okpechi, I.G., Chukwuonye, I.I., Tiffin, N., Madukwe, O.O., Onyeonoro, U.U., Umeizudike, T.I., et al. Blood Pressure Gradients and Cardiovascular Risk Factors in Urban and Rural Populations in Abia State South Eastern Nigeria Using the WHO STEPwise Approach. PLoS ONE. 2013;8(9):e73403. 27. Suleiman, I.A., Amogu, E.O., Ganiyu, K.A. Prevalence and control of hypertension in a Niger Delta semi urban community, Nigeria. Pharmacy Practice 2013;11(1):24-9. Available from: https://www.ncbi.nlm.nih.gov/pmc/articles/PMC3780 508/.

28. Abah, I. Hypertension prevalence, knowledge, attitude \& awareness among pharmacists in Jos, Nigeria. West Afr J Pharmacy 2014;25(2):98-106.

29. Abu-Saeed, K., Odili, V.U., Muslim, J.O. High Prevalence of Hypertension among Residents of Ilorin. J Sci Pract Pharmacy 2014;1(1):54-8. Available from: http://www.jsppharm.org/home/abstract.php?id=11\& aTitle=High $\% 20$ Prevalence $\% 20$ of $\% 20$ Hypertension \%20among\%20Residents\%20of\%20Ilorin.

30. Adamu, H., Makusidi, A.M., Liman, H.M., Isah, M.D., Jega, M.R., Chijioke, A. Prevalence of Obesity, Diabetes Type 2 and Hypertension among a Sampled Population from Sokoto Metropolis-Nigeria. J Advances Med Med Res 2014;4(10):2065-80.

31. Ale, O., Ajuluchukwu, J., Oke, D., Mbakwem, A. Impact of prehypertension on left ventricular mass and QT dispersion in adult black Nigerians. Cardiovasc $\mathbf{J}$ Afr 2014;25(2):78-82.

32. Ganiyu, K., Kpokiri, E., Omoshue, O. Prevalence of Undiagnosed Elevated Blood Pressure in Okparabe Community in Southern Nigeria. J Sci Pract Pharm 2014;1(1):59-62.

33. Okafor, C.N., Young, E.E., Nwobi, E.A., Ike, S.O. Cardiovascular risk factors in a population of rural women in south-east Nigeria. Afr J Med Med Sci 2014;43(Suppl 1):225-32.

34. Egbuonu, A.C.C., Egbuonu, O.N.C., Akabogu, N., Udensi, Z.I., Ugwo, U.O., Ejidike, A.G. The Prevalence And Demographic Pattern Of Obesity And Its Correlates In Undergraduates Of Michael Okpara University Of Agriculture Umudike South-East, Nigeria. J Environ Toxicol Public Health 2015;1(1):11-17.

35. Egbi, O.G., Rotifa, S., Jumbo, J. Prevalence of hypertension and its correlates among employees of a tertiary hospital in Yenagoa, Nigeria. Anna Afr Med 2015;14(1):8-17.

36. Guwatudde, D., Nankya-Mutyoba, J., Kalyesubula, R., Laurence, C., Adebamowo, C.,
Ajayi, I., et al. The burden of hypertension in subSaharan Africa: A four-country cross sectional study. BMC Public Health. 2015;15(1):1211.

37. Okwuonu, C.G., Ngoka, S.C., Chimezie, O.J., Eze, T.H., Uwanurochi, K., Mbanaso, A.U. Towards prevention of hypertension in Nigeria: A study of prehypertension and its associations among apparently healthy adults in Umuahia, South-East Nigeria. Int J Prev Med 2015;6:61.

38. Oladoyinbo, C.A., Ekerette, N.N., Ogunubi, T.I. Obesity and Hypertension amongst Traders in Ijebu Ode, Nigeria. Afr J Biomed Res 2015;18(1):23-7.

39. Tagurum, Y.O., Okoh, O.E., Inalegwu, E., Ozoilo, J.U., Banwat, M.E., Zoakah, A.I. Non-communicable diseases: Prevalence and Risk Factors among Adults in a Rural Community in Plateau State, Nigeria.Int J Biomed Res 2015;6(4):228-234. Available from: http://irepos.unijos.edu.ng/jspui/handle/123456789/1 083.

40. . Uwah, A., Idongesit, N., Uka, E. Prevalence of hypertension among adults attending Faith-based Centres in Abak Township, Akwa Ibom State, Nigeria. Merit Res J Med Med Sci 2015;3)7):245-8.

41. Adeoye, A.M., Adebiyi, A., Owolabi, M.O., Lackland, D.T., Ogedegbe, G., Tayo, B.O. Gender disparity in blood pressure levels among Nigerian health workers. J Clin Hypertens 2016;18(7):685-9. 42. Ajayi, I., Sowemimo, I., Akpa, O., Ossai, N. Prevalence of hypertension and associated factors among residents of Ibadan-North Local Government Area of Nigeria. Niger J Cardiol 2016;13(1):67-75.

43. Ayanniyi, O., Akinremi, A., Odunnaiya, N., Adenaike, I. Cardiovascular disease risk among professionals: A survey of modifiable risk factors among teachers in an urban community. Highland Med Res J 2016;16(1):1-6.

44. Kooffreh, M.E., Abasiodiong, M.G. Differences in Blood Pressure Levels and Its Association with Obesity Indices among Traders in Watt Market Calabar, Cross River State Nigeria. Sch Acad Biosci 2016;4(7):565-70.

45. Mmom, F.C., Chuemere, A.N. A Study of Incidence and Prevalence of Hypertension, Diabetes and Obesity with Blood Type in Postmenopausal Females in Port Harcourt. Saudi J Biomed Res 2016;1(1):22-9.

46. Olamoyegun, M., Iwuala, S., Asaolu, S., Oluyombo, R. Epidemiology and patterns of hypertension in semi-urban communities, southwestern Nigeria. Cardiovasc J Afr 2016;27(6):356-60. 47. Ononamadu, C.J., Ezekwesili, C.N., Onyeukwu, O.F., Umeoguaju, U.F., Ezeigwe, O.C., Ihegboro, G.O. Comparative analysis of anthropometric indices of obesity as correlates and potential predictors of risk 
for hypertension and prehypertension in a population in Nigeria. Cardiovasc J Afr 2017;28(2):92-9.

48. Aladeniyi, I., Adeniyi, O., Owolabi, E., Fawole, O., Adeolu, M., Ter Goon, D., et al. Prevalence, Awareness and Correlates of Hypertension Among Urban Public Workers in Ondo State, Nigeria. Online J Health Allied Sci 2017;16(3):1-6.

49. Ayodele, O.E., Akanbi, O.O., Akinwusi, P.O., Hassan, A.O., Ogunro, P.O. Urinary Abnormalities, Blood Pressure and Anthropometric Profiles Among Students in a Nigerian University. Trop J Nephrol 2009;4(1):21-9. Available from: http://www.tjnonline.com/index.php/tjn/article/view/91.

50. Ejike, C.E.C.C., Ukegbu, P.O. Not a 'Straitjacket Affair': Anthropometrically Derived Obesity Index Correlates of Elevated Blood Pressure among University Undergraduates. Med Sci 2017;5(2):9.

51. Nwatu, C.B., Young, E.E., Okwara, C.C., Okoli, C.E., Obi, P.C., Anyim, O.B., et al. Concurrent Prediabetes and Prehypertension in a Rural Community in South East Nigeria. J Advances Medicine Medical Res 2017;22(3):1-10.

52. Ambakederemo, T.E., Chikezie, E.U. Assessment of some traditional cardiovascular risk factors in medical doctors in Southern Nigeria. Vasc Health Risk Manag 2018;14:299-309.

53. Bello-Ovosi, B.O., Asuke, S., Abdulrahman, S.O., Ibrahim, M.S., Ovosi, J.O/, Ogunsina. M.A., et al. Prevalence and correlates of hypertension and diabetes mellitus in an urban community in North-Western Nigeria. Pan Afr Med J 2018;29(1):1-7.

54. Dokunmu, T.M., Yakubu, O.F., Adebayo, A.H., Olasehinde, G.I., Chinedu, S.N. Cardiovascular Risk Factors in a Suburban Community in Nigeria. Int J Hypertens 2018;2018:e6898527.

55. Egbi, O., Ogoina, D., Oyeyemi, A. Prevalence of hypertension and associated factors in a rural community in Bayelsa State. Int $\mathrm{J}$ Res Med Sci 2018;6:1106-1113.

56. Ibuaku, C., Nwajei, A., Queen, A. Anthropometric Assessment of Nutritional Status of Adults in a NonConflict Environment of the Niger-Delta Region of Nigeria. Int Res J Pharm Med Sci 2018;1(5):46-9.

57. Nkechi, O.I. Prevalence and Predictors of Overweight, Obesity and Hypertension among Undergraduates of a Southern Nigerian University. J Med Sci Clin Res 2018;6(12):1-9.

58. Ofori, S.N., Fobil, J.N., Odia, O.J. Household biomass fuel use, blood pressure and carotid intima media thickness; a cross sectional study of rural dwelling women in Southern Nigeria. Environ Pollut 2018;242(Pt A):390-7.

59. Olatona, F.A., Onabanjo, O.O., Ugbaja, R.N., Nnoaham, K.E., Adelekan, D.A. Dietary habits and metabolic risk factors for non-communicable diseases in a university undergraduate population. J Health Popul Nutr 2018;37(1):21.

60. Shittu, R.O., Odeigah, L.O., Fakorede, K.O., Sikiru, B.A., Sule, A.G., Musah, Y., et al. Prevalence and correlates of hypertension-outcome of a free medical screening in Oke-Ogun area of Oyo state, Nigeria, West Africa. J Am Soc Hypertens 2018;12(4):268-74.

61. Wordu, G., Akusu, O.M. Dietary Pattern and Prevalence of High Blood Pressure among Adult Traders in Port Harcourt, Nigeria. Asian J Med Health 2018;11(1):1-7.

62. Adelowo A, Mercy O. An Assessment of the Prevalence of Diabetes Mellitus and Its Risk Factors among People Living in Abuja, Nigeria. J Int Council Health Physical Educ Recreat Sport Dance 2019;5(1):171-86.

63. Adenrele, H., Mercy, O., Adelowo, A. Cardiometabolic risk assessment among corporate workforce in Abuja. Nigeria. J Res Contemporary Issues in Human Kinetics Health Educ 2020;4(1):27-41. Available

from: https://www.researchgate.net/publication/347389567

_JOURNAL_OF_RESEARCH_AND_CONTEMPO RARY_ISSUES_IN_HUMAN_KINETICS_AND_H EALTH_EDUCATION_PEER-

REVIEWED_JORCIHKHE_2018_4_1_27_-

41_CARDIO-

METABOLIC_RISK_ASSESSMENT_AMONG_C ORPORATE_WORKFORCE_IN_ABUJA_NIGERI A_J.

64. Ajayi, D.D., Deji, S.A., Odu, O.O., Dada, S.A., Amu, E.O., Marcus, O. Cardiovascular Disease Risk Factors Assessment of Women Attending a Religious Program in Ado Ekiti, Nigeria. Am J Biomed Life Sci 2019;7(2):36-41.

65. Obiebi, I.P., Aiwuyo, H.O. 2017 American College of Cardiology/American Heart Association Clinical Guideline-based Prevalence of Hypertension in a semi-urban community in Nigeria: Public Health Perspective. Revista Colombiana de Cardiología 2019;26(6):346-53.

66. Okubadejo, N.U., Ozoh, O.B., Ojo, O.O., Akinkugbe, A.O., Odeniyi, I.A., Adegoke, O., et al. Prevalence of hypertension and blood pressure profile amongst urban-dwelling adults in Nigeria: A comparative analysis based on recent guideline recommendations. Clin Hypertens 2019;25:7.

67. Yakubu, I.M., Bigelow, P. Prevalence and Determinants of Overweight, Obesity, Prehypertension, and Hypertension in the Banking Industry in Nigeria: An Analysis of a Nationwide Dataset. Texila Int J Pub Health 2019;7(4):1-13.

68. Banigbe, B.F., Itanyi, I.U., Ofili, E.O., Ogidi, A.G., Patel, D., Ezeanolue, E.E. High prevalence of 
undiagnosed hypertension among men in North Central Nigeria: Results from the Healthy Beginning Initiative. PLoS One 2020;15(11):e0242870.

69. Dada, I.O., Igbe, I.A. Feeding habits, Overweight, Obesity and Hypertension and Associated Factors among Polytechnic Students in Ekiti State, Southwest Nigeria. J Multidisciplinary Res Healthcare. 2020;7(1):33-48.

70. Odili, A.N., Chori, B.S., Danladi, B., Nwakile, P.C., Okoye, I.C., Abdullahi, U., et al. Prevalence, Awareness, Treatment and Control of Hypertension in Nigeria: Data from a Nationwide Survey 2017. Glob Heart 2020; 15(1):47.

71. Odunaiya, N., Okoye, E., Adegoke, O., Ojoye, D., Ooguntibeju, O. High Prevalence and Clustering Of Modifiable Cardiovascular Disease Risk Factors among Nurses in Nigeria: Implication for Translating Knowledge into Practice among Health Care Professionals. Int J Pub Health Safe 2020;5(6):1-7.

72. Olaitan, O.O., Olanrewaju, O.I., Akinmoladun, F.O., Fadupin, G. Central Obesity and StressPredisposing Factors to Hypertension among Health Workers in Jos University Teaching Hospital, Plateau State, Nigeria. Cur Res Diabetes Obesity J 2020;12(4):111-116.

73. Olawade, D., Afolalu, T., Wada, O., Barka, I. Evaluations of Hypertension among Adult Residents of Tinda Rural Community, Nigeria. Int J Pub Health Epidemiol Res 2020;6(2):157-62.

74. Raimi, T., Odusan, O. Association of hypertension with generalized obesity in rural south-western Nigeria. J Surg Med 2020;4(3):177-81.

75. . Umuerri, E.M., Aiwuyo, H.O. Prevalence and correlates of prehypertension and hypertension among adults in Delta State, Nigeria: A cross-sectional community-based study. Ghana Med J 2020;54(1):4857.

76. Upla, P.U., Sani, B., Hadi, N.S., Anbalaga, G.A., Anura, F., Bassey, M.I., et al. Prevalence Of Hypertension Among Residents Of Alakio Community, Lafia East Development Area, Nasarawa State. Int $\mathbf{J}$ Innovative Res Advanced Studies 2020;7(4):177-181.

77. Wada, O.Z., Olawade, D.B., Afolalu, T.D., Oluwatofarati, A.O., Akinwalere, I.G. Prevalence of Hypertension among Rural Adults and Availability of Management Services in Abimbola Community, Ayedaade Local Government Area, Osun State, Nigeria. J Hypertens Manag 2020;6(1):046.

78. Opreh, O.P., Olajubu, T.O., Akarakiri, K.J., Ligenza, V., Amos, J.T., Adeyeye, A.V., et al. Prevalence and factors associated with hypertension among rural community dwellers in a local government area, South West Nigeria. Afr Health Sci 2021;21(1):75-81.
79. Harrer, M., Cuijpers, P., Furukawa, T.A., Ebert, D.D. Doing Meta-Analysis with R: A Hands-On Guide. Chapman and Hall Book, CRC Group, 2021. Available from: https://www.routledge.com/DoingMeta-Analysis-with-R-A-Hands-On-Guide/HarrerCuijpers-Furukawa-Ebert/p/book/9780367610074.

80. Booth, J.N., Li, J., Zhang, L., Chen, L., Muntner, P., Egan, B. Trends in Prehypertension and Hypertension Risk Factors in US Adults. Hypertension 2017;70(2):275-84.

81. Joffres, M., Falaschetti, E., Gillespie, C., Robitaille, C., Loustalot, F., Poulter, N., et al. Hypertension prevalence, awareness, treatment and control in national surveys from England, the USA and Canada, and correlation with stroke and ischaemic heart disease mortality: A cross-sectional study. BMJ Open 2013 ;3(8):e003423.

82. Jin, N., Li, G., Li, H., Chen, L., Leng, B. [Incidence and risk factors of prehypertension among adults in mainland China: a meta-analysis]. Nan fang yi ke da xue xue bao(J Southern Med Uni) 2013;33(12):173843.

83. Afsargharehbagh, R., Rezaie-Keikhaie, K., Rafiemanesh, H., Balouchi, A., Bouya, S., Dehghan, B. Hypertension and Pre-Hypertension Among Iranian Adults Population: A Meta-Analysis of Prevalence, Awareness, Treatment, and Control. Curr Hypertens Rep 2019;21(4):27.

84. Huang, Y., Guo, P., Karmacharya, B.M., Seeruttun, S.R., Xu, D.R., Hao, Y. Prevalence of hypertension and prehypertension in Nepal: A systematic review and meta-analysis. Glob Health Res Policy 2019;4(1):11.

85. Dosoo, D.K., Nyame, S., Enuameh, Y., Ayetey, H., Danwonno, H., Twumasi, M., et al. Prevalence of Hypertension in the Middle Belt of Ghana: A Community-Based Screening Study. Int J Hypertens 2019;2019:e1089578.

86. Tripathy, J.P., Thakur, J.S., Jeet, G., Chawla, S., Jain, S. Alarmingly high prevalence of hypertension and pre-hypertension in North India-results from a large cross-sectional STEPS survey. PLoS One 2017;12(12):e0188619. 